\title{
Correlation of the Gastrointestinal Parasitism with the Phytominerals in the Grazing Sheep (Ovis aries)
}

\author{
Hafiz Muhammad Rizwan ${ }^{*}$, Muhammad Sohail Sajid ${ }^{2,3}$, Zafar Iqbal' ${ }^{2}$, Raziya Nadeem ${ }^{4}$, Mansoor Ahmad ${ }^{2,5}$, Masood \\ Sultan $^{6}$, Muhammad Saqib ${ }^{7}$, Haider Abbas ${ }^{1}$, Asim Shamim ${ }^{8}$, Abdul Qudoos ${ }^{9}$ and George FW Haenlein ${ }^{10}$ \\ ${ }^{1}$ Section of Parasitology, Department of Pathobiology, College of Veterinary and Animal Sciences, Narowal Sub campus \\ UVAS, Lahore, Pakistan \\ ${ }^{2}$ Department of Parasitology, University of Agriculture, Faisalabad, Pakistan \\ ${ }^{3}$ One Health Lab. Center for Advanced Studies in Agriculture and Food Security, University of Agriculture, Faisalabad, \\ Pakistan \\ ${ }^{4}$ Department of Chemistry, University of Agriculture, Faisalabad, Pakistan \\ ${ }^{5}$ Veterinary Officer, Mobile Veterinary Dispensary, Chiniot, Pakistan \\ ${ }^{6}$ Department of Microbiology, University of Agriculture, Faisalabad, Pakistan \\ ${ }^{7}$ Department of Clinical Medicine and Surgery, University of Agriculture, Faisalabad, Pakistan \\ ${ }^{8}$ Department of Pathobiology, University of Poonch Rawalakot, Azad Kashmir \\ ${ }^{9}$ Central Hi-Tech Laboratory, University of Agriculture, Faisalabad, Pakistan \\ ${ }^{10}$ Department of Animal and Food Sciences, University of Delaware, USA \\ *For correspondence: hm.rizwan@uvas.edu.pk \\ Received 06 February 2021; Accepted 06 April 2021; Published 10 June 2021
}

\begin{abstract}
Trace elements play an important role to boost the immunity and fight against parasitic infections. Concentration of trace elements like Copper $(\mathrm{Cu})$, Cobalt $(\mathrm{Co})$, Manganese $(\mathrm{Mn})$ and Zinc $(\mathrm{Zn})$ were determined in soil, forages and sera of sheep. An associative analysis was also made between the burden of Gastrointestinal (GI) parasites and concentrations of trace elements of sheep sera. For this, 384 faecal and blood samples of sheep, an appropriate number of forages and soil samples were collected. The faecal samples were subjected to determine the species and burden of GI parasites. The sera, plant and soil samples were subjected to pre-treatment (digestion) required for the determination of trace elements. The overall prevalence of GI parasites was $32.81 \%$ and the most prevalent species were Haemonchus (H.) contortus followed in order by Eimeria spp., Strongyloides spp., Trichostrongylus spp. and Fasciola spp. Variables like age, sex, breed and tehsils of Silakot district showed an insignificant association with GI parasitic burden. Trace elements concentration of forages showed a significant $(P$ $<0.05)$ variation while trace elements concentration of soil showed an insignificant $(P>0.05)$ variation. In serum, $\mathrm{Zn}$ concentration showed significant $(P<0.05)$ results among all the tehsils of study district. Mean concentrations of $\mathrm{Mn}$ and $\mathrm{Cu}$ in serum were found inversely proportional to the mean egg count per gram of sheep faeces in tehsil Pasroor of the Sialkot district. Forages containing high concentrations of $\mathrm{Mn}$ and $\mathrm{Cu}$ can be used effectively against GI parasites. (C) 2021 Friends Science Publishers
\end{abstract}

Keywords: Sheep; Trace Elements; Forages; Soil; Sera; Gastrointestinal parasites

\section{Introduction}

The livestock sector especially small ruminants rearing is one of the major and more secure sources of income for smallholder farmers around the world (Terefe et al. 2012). Small ruminants farming can comparatively require small inputs like startup investment, maintenance, feedstuffs, and expenditure as compared to the bovine population (Caroprese et al. 2016). The main purpose of sheep raising is to fulfill the needs of mutton and wool production (Khan et al. 2007). Parasitic diseases, one of the principal problems in the development of commercial livestock business, are facilitated through favorable climatic conditions and lack of awareness. About $90 \%$ of the sheep population around the world suffers from various kinds of parasitic diseases (Mohanta et al. 2007; Biu et al. 2009; Kanyari et al. 2009; Raza et al. 2014; Rizwan et al. 2017; Qudoos et al. 2017; Rizwan et al. 2019; Ahmad et al. 2020).

In the developing countries, anti-parasitic drugs are used lavishly for the control of parasitic infections especially by smallholder farmers which may lead to the development of resistance. Other factors responsible for the

To cite this paper: Rizwan HM, MS Sajid, Z Iqbal, R Nadeem, M Ahmad, M Sultan, M Saqib, H Abbas, A Shamim, A Qudoos, GFW Haenlein (2021). Correlation of the gastrointestinal parasitism with the phytominerals in the grazing sheep (Ovis aries). Intl J Agric Biol 26:60-68 
development of resistance are; poor efficacy of antiparasitic agents, low protein diet, insufficient dose level, and environmental toxicity (Smith and Sherman 2009; Khan et al. 2017). Development of resistance against anthelmintics and their residual effects stimulate scientists to investigate alternative sources to control parasitic infection and to improve public health (Qadir et al. 2010). During the past decade, uses of plants with anthelmintic properties (ethnoveterinary medicine) are under considerations around the world (Lateef et al. 2003; Peixoto et al. 2015; Tugume et al. 2016; Kebede et al. 2017; Badar et al. 2017).

Nutrition has the potential to affect the GI parasites because it directly affects the degree of expression of immunity and rate of acquisition which influence the survival, fecundity, and establishment of the GI parasites (Fekete and Kellems 2007). Mineral's availability in an appropriate quantity is a pre-requisite for the health and productivity of livestock, while insufficient mineral intake or unavailability decreases productivity (Khan et al. 2007). Under natural grazing conditions, forage plants are the major source for herbivores to obtain minerals. Apart from this source, water and soil also contribute to acquiring considerable quantities of minerals. Determination of trace elements in grazing forages and their bioavailability to the animals is important to regulate the requirement of animals (Khan et al. 2007; Qudoos et al. 2017; Rizwan et al. 2019; Ahmad et al. 2020). Grazing of animals in rangelands containing trace elements rich forages increases the resilience against parasitic infections particularly in resource-poor countries like Pakistan.

\section{Materials and Methods}

\section{Study area and animals}

The study was conducted in district Sialkot $\left(32^{\circ} 30^{\prime} 0^{\prime \prime} \mathrm{N} / 74^{\circ}\right.$ $31^{\prime} 0$ " E), Punjab, Pakistan which has three administrative divisions (tehsils) named; (a) Daska, (b) Pasroor and (c) Sialkot. The topography of Sialkot is plain and fertile. About $25.82 \%$ of the population lives in urban areas. The highest temperature in summer may reach $49^{\circ} \mathrm{C}$ and lowest $2^{\circ} \mathrm{C}$ during winter. The average rainfall in the study district is about $1000 \mathrm{~mm}$ annually. The study animals included indigenous breeds of sheep (Ovis aries). The total population of sheep in the Sialkot district is 87,000 (Anonymus 2016). The samples were collected from the grazing meadows of the study district by using a simple random sampling method. A total of 384 sheep of different age, sex and breeds were screened from Sialkot district. The present study was approved by Research Ethics Committee of Faculty of Veterinary Medicine, University of Agriculture, Faisalabad, Pakistan.

\section{Collection and coprological examination of faeces}

Collection of faeces $(n=384)$ was done using standard protocols, briefly, $10 \mathrm{~g}$ of faecal sample was collected directly from rectum and stored in plastic bottles containing $10 \%$ formalin. After proper labeling to, plastic bottles were transported to Molecular Parasitology Laboratory, University of Agriculture, Faisalabad for further processing. The qualitative faecal examination was done by floatation and sedimentation methods while the quantitative faecal examination was done by Modified McMaster egg counting technique briefly, $3 \mathrm{~g}$ of faeces was mixed in $45 \mathrm{~mL} \mathrm{NaCl}$ (flotation) solution. After straining, the chamber was filled to suspension and allowed to settle for 3 to $5 \mathrm{~min}$. Counting of eggs was done carefully under a compound microscope at 10x in each lane of the chamber (Soulsby 1982). Species of parasites were identified on the basis of egg size and shape. Eggs per gram faeces from 100 to 800 was considered light infection, 801 to 1200 moderate and more than 1200 high infection (Table 2).

\section{Collection and digestion of soil samples for elemental analysis}

Representative soil samples of the selected grazing sites from each tehsil of the study district were collected. Soil samples of various depths $(15,30,60,90$ and $120 \mathrm{~cm})$ were collected with a sampling auger. Five different locations of each grazing field were selected and $200 \mathrm{~g}$ sample from each location was collected. All samples from each selected grazing site were mixed thoroughly to make a cumulative representative sample of $1000 \mathrm{mg}$.

Soils samples were macerated with a pestle and mortar and filtered through $0.2 \mathrm{~mm}$ sieve and dried at room temperature for $24 \mathrm{~h}$. One $\mathrm{g}$ of the dried soil was taken into a $50 \mathrm{~mL}$ conical flask, mixed with the concentrated $\mathrm{HNO}_{3}$ $(10 \mathrm{~mL})$ and kept for $12 \mathrm{~h}$ at room temperature. After that, substances in the flask were heated, $\mathrm{HNO}_{3}(1 \mathrm{~mL})$ and $\mathrm{HClO}_{4}(4 \mathrm{~mL})$ were added and heated again $\left(200^{\circ} \mathrm{C}\right)$. After cooling, $5 \mathrm{~mL} \mathrm{1:10} \mathrm{HCl}$ was added followed by heating at $70^{\circ} \mathrm{C}$ till the volume remained $2 \mathrm{~mL}$. After cooling, deionized water was added to make the volume of $50 \mathrm{~mL}$ (Amacher 1996). The mixture was filtered through Whatman filter paper No. 42 and stored until further analyses.

\section{Collection and digestion of forages for elemental analysis}

Forages were collected from the selected grazing sites of each tehsil of the study district. Collected species of plants were packed in zip tight bags, labeled properly with all relevant information, and transported to U.A.F. Samples were identified by a professional of the Botany Department, U.A.F.

Collected forage specimens were subjected to pretreatment for determination of mineral profile. Briefly, leaves of collected plants were washed with water and then with $1 \% \mathrm{HCl}$. After washing, the forage leaves were dried in the air and then in the oven at $65^{\circ} \mathrm{C}$. Dried plant materials were subjected to an electric grinding machine to make 
powder and stored till digestion. Dried forages (1 $\mathrm{g}$ each) were taken in flasks mixed with $5 \mathrm{~mL}$ concentrated $\mathrm{HNO}_{3}$ and $5 \mathrm{~mL} \mathrm{HClO}_{4}(5 \mathrm{~mL})$ and kept overnight. The next day, five $\mathrm{mL} \mathrm{HNO}_{3}$ was added and heated until the material became clear. After cooling, $50 \mathrm{~mL}$ of de-ionized water was added (Miller 1998) and filtered through Whatman filter No. 42. The pre-treated plant samples were submitted to the Central Hi-Tech Laboratory, UAF for mineral profile determination using standard protocols (Haswell 1991).

\section{Collection and digestion of sera samples for elemental analysis}

Five $\mathrm{mL}$ blood was collected from the selected sheep $(\mathrm{n}=$ 384) into commercially available gel clot activating vacutainers and labeled with the age, sex, breed and other relevant detail before transporting to the Parasitology Department, UAF. The blood was centrifuged for $15 \mathrm{~min}$ at $2000 \mathrm{x} g$ and the serum was separated. If the serum samples were not analyzed immediately after separation; these were stored at $-20^{\circ} \mathrm{C}$ until further processing.

Wet digestion of the collected sera samples was done as suggested by Richards (1968). Briefly, one mL serum was mixed with concentrated $\mathrm{HNO}_{3}(10 \mathrm{~mL})$ into a digestion flask and heated for $15 \mathrm{~min}$ at $60^{\circ} \mathrm{C}$. After cooling, five $\mathrm{mL} \mathrm{HClO}_{4}$ was added and heated again till the volume remained one $\mathrm{mL}$. After cooling, $25 \mathrm{~mL}$ de-ionized water was added and samples were subjected to determination of minerals through spectrophotometry.

The concentration of $\mathrm{Cu}, \mathrm{Co}, \mathrm{Zn}$, and $\mathrm{Mn}$ from digested soil, forages and sera were analyzed with atomic absorption spectrophotometer (in triplicates) as defined by Haswell (1991).

\section{Statistical analyses}

The relationships of independent variables like age, sex, location and breed of sheep with the prevalence of GI parasites were determined using the Chi-square test. One way analysis of variance was applied to determine the differences of trace elemental profile in soil, forages and serum samples. Each soil, plant, and serum sample was analyzed in triplicate to determine their mean values and standard error of the mean to estimate the variability between samples. Pearson's correlation method was used to correlate the trace element profile of serum with respective EPG values (Schork and Remington 2010). $P$-value of $<$ 0.05 was considered statistically significant. All statistical analyses were performed by Minitab 17 statistical software.

\section{Results}

\section{Species and burden of gastrointestinal parasites}

Among 384 screened faecal samples, the overall prevalence of GI parasites was $32.81 \%$. The species of parasites identified from the collected faecal samples were Haemonchus $($ H.) contortus $(32.81 \%)$ followed in order by Eimeria spp. (23.70\%), Strongyloides spp. (18.75\%), Trichostrongylus spp. (15.36\%) and Fasciola spp. (7.55\%). The prevalence of $H$. contortus, Trichostrongylus spp. and Fasciola spp. were higher in adult animals while prevalence of Eimeria spp. and Strongyloides spp. were higher in young animals. The prevalence of all the identified species of parasites was significantly higher in female as compared to male. However, the prevalence of these species was insignificant in different breeds of sheep and tehsils of Sialkot district (Table 1).

The burden of gastrointestinal parasitic infection of sheep in relation to age, sex, breed and tehsils of Sialkot district, Punjab, Pakistan were insignificant (Table 2). Most of the adult and female animals showed high burden of parasitic infection followed in order by moderate and low. However, the order of the burden of parasites in young animals was high, low and moderate while in male animals was moderate, high and low. Among breeds, most of the animals of Thalli, Fat tailed and Kajli breed showed moderate infection while Salt range breed showed low infection. Among tehsils, most of the animals of all tehsils showed high burden of parasitic infection.

\section{Trace elements profile of forages in district and tehsils of Sialkot}

Eight forage species include; Amaranthus viridis, Cannabis sativa, Echinochloa colona, Fagonia indica, Parthenium hysterophorus, Cynodon dactylon, Brachiaria ramose and Cyperus rotundus were identified from Sialkot district to be consumed by sheep. A significant variation in the concentration of selected trace elements was observed in all collected forages (Table 3). Highest concentration (39.79 \pm $0.11 \mathrm{mg} / \mathrm{kg}$ ) of $\mathrm{Zn}$ was found in Echinochloa colona while, minimum $(19.35 \pm 0.32 \mathrm{mg} / \mathrm{kg})$ in Amaranthus viridis. Maximum concentration $(44.83 \pm 0.14 \mathrm{mg} / \mathrm{kg})$ of $\mathrm{Cu}$ was found in Amaranthus viridis and minimum (21.53 \pm 0.07 $\mathrm{mg} / \mathrm{kg}$ ) in Brachiaria ramosa. Cannabis sativa and Parthenium hysterophorus contained maximum (36.91 \pm $0.17 \mathrm{mg} / \mathrm{kg})$ and minimum (17.11 $\pm 0.03 \mathrm{mg} / \mathrm{kg})$ concentrations of $\mathrm{Mn}$, respectively. Brachiaria ramose showed maximum concentration of Co $(1.48 \pm 0.02 \mathrm{mg} / \mathrm{kg})$ while Parthenium hysterophorus showed minimum (0.87 \pm $0.05 \mathrm{mg} / \mathrm{kg}$ ).

Mean concentrations of all the selected trace elements were insignificant among different tehsils of the Sialkot district. Maximum concentration $(34.71 \pm 6.33 \mathrm{mg} / \mathrm{kg})$ of $\mathrm{Zn}$ was found in the forages of tehsil Daska while forages from tehsil Sialkot contained minimum (26.84 \pm 7.51 $\mathrm{mg} / \mathrm{kg}$ ) concentration. Forages of tehsil Sialkot showed maximum concentration of $\mathrm{Cu}(38.35 \pm 7.01 \mathrm{mg} / \mathrm{kg})$ whereas, it was minimum $(30.00 \pm 7.78 \mathrm{mg} / \mathrm{kg})$ in forages from tehsil Daska. Maximum mean concentration of $\mathrm{Mn}$ (33.34 $\pm 8.39 \mathrm{mg} / \mathrm{kg}$ ) was found in forages collected from 
Trace Elements and Parasitic Infections / Intl J Agric Biol, Vol 26, No 1, 2021

Table 1: Frequency distribution of gastrointestinal parasitic species in sheep population of Sialkot district

\begin{tabular}{lllllll}
\hline Variable & Level & Haemonchus contortus $(\%)$ & Eimeria spp. (\%) & Strongyloides spp. (\%) & Trichostrongylus spp. (\%) & Fasciola spp. (\%) \\
\hline Age & Adult & $72(57.14)$ & $34(37.36)$ & $32(44.44)$ & $38(64.41)$ & $17(58.62)$ \\
& Young & $54(42.86)$ & $57(62.64)$ & $40(55.56)$ & $21(35.59)$ & $12(41.38)$ \\
Sex & Male & $41(32.54)$ & $25(27.47)$ & $29(40.28)$ & $25(42.37)$ & $11(37.93)$ \\
& Female & $85(67.46)$ & $66(72.53)$ & $43(59.72)$ & $34(57.63)$ & $18(62.07)$ \\
Breed & Thalli & $28(22.22)$ & $18(19.78)$ & $14(19.44)$ & $13(22.03)$ & $8(27.59)$ \\
& Salt range & $34(26.98)$ & $27(29.67)$ & $19(26.39)$ & $16(27.12)$ & $5(17.24)$ \\
& Fat tailed & $32(25.40)$ & $21(23.08)$ & $17(23.61)$ & $19(32.20)$ & $9(31.03)$ \\
& Kajli & $32(25.40)$ & $25(27.47)$ & $22(30.56)$ & $11(18.64)$ & $7(24.14)$ \\
Tehsils & Daska & $45(35.71)$ & $31(34.07)$ & $30(41.67)$ & $24(40.68)$ & $11(37.93)$ \\
& Sialkot & $44(34.92)$ & $35(38.46)$ & $23(31.94)$ & $16(27.12)$ & $8(27.59)$ \\
& Pasror & $37(29.37)$ & $25(27.47)$ & $19(26.39)$ & $19(32.20)$ & $10(34.48)$ \\
\hline
\end{tabular}

Table 2: Burden of gastrointestinal parasitic infection of sheep in relation to age, sex, breed and tehsils of Sialkot district, Punjab, Pakistan

\begin{tabular}{|c|c|c|c|c|c|c|}
\hline Variable & Level & Light (\%) & Moderate (\%) & High (\%) & $\chi^{2}$ & $P$-value \\
\hline \multirow[t]{2}{*}{ Age } & Adult & $14(19.44)$ & $22(30.56)$ & $36(50.00)$ & 3.993 & 0.136 \\
\hline & Young & $19(35.19)$ & $14(25.93)$ & $21(38.89)$ & & \\
\hline \multirow[t]{2}{*}{ Sex } & Male & $8(19.51)$ & $18(43.90)$ & $15(36.59)$ & 2.053 & 0.358 \\
\hline & Female & $24(28.24)$ & $27(31.76)$ & $34(40.00)$ & & \\
\hline \multirow[t]{4}{*}{ Breed } & Thalli & $8(28.57)$ & $11(39.29)$ & $9(32.14)$ & 4.531 & 0.605 \\
\hline & Salt range & $15(44.12)$ & 7 (20.59) & $12(35.29)$ & & \\
\hline & Fat tailed & $10(31.25)$ & $13(40.63)$ & $9(28.13)$ & & \\
\hline & Kajli & $9(28.13)$ & $12(37.50)$ & $11(34.38)$ & & \\
\hline \multirow[t]{3}{*}{ Tehsils } & Daska & $14(31.11)$ & $7(15.56)$ & $24(53.33)$ & 8.101 & 0.088 \\
\hline & Sialkot & $7(15.91)$ & $17(38.64)$ & $20(45.45)$ & & \\
\hline & Pasror & $10(27.03)$ & 7 (18.92) & $20(54.05)$ & & \\
\hline
\end{tabular}

Light $=100-800 ;$ Moderate $=801-1200 ;$ High $=>1200$

Table 3: Mean concentrations of $\mathrm{Cu}, \mathrm{Zn}, \mathrm{Co}$ and $\mathrm{Mn}$ in forages collected from Sialkot district, Punjab, Pakistan preferred by the grazing sheep population

\begin{tabular}{|c|c|c|c|c|}
\hline Forages species & $\mathrm{Zn}(\mathrm{mg} / \mathrm{kg})$ Mean $\pm \mathrm{SE}$ & $\mathrm{Cu}(\mathrm{mg} / \mathrm{kg}) \mathrm{Mean} \pm \mathrm{SE}$ & $\mathrm{Mn}(\mathrm{mg} / \mathrm{kg})$ Mean $\pm \mathrm{SE}$ & Co $(\mathrm{mg} / \mathrm{kg})$ Mean $\pm \mathrm{SE}$ \\
\hline Amaranthus viridis & $19.35 \pm 0.32^{\mathrm{d}}$ & $44.83 \pm 0.14^{\mathrm{a}}$ & $30.52 \pm 0.33^{\mathrm{bc}}$ & $1.42 \pm 0.03^{\mathrm{a}}$ \\
\hline Cannabis sativa & $24.71 \pm 0.15^{\mathrm{cd}}$ & $30.33 \pm 0.12^{\mathrm{c}}$ & $36.91 \pm 0.17^{\mathrm{a}}$ & $0.98 \pm 0.05^{\mathrm{a}}$ \\
\hline Echinochloa colona & $39.79 \pm 0.11^{\mathrm{a}}$ & $36.28 \pm 0.12^{\mathrm{ab}}$ & $29.29 \pm 0.06^{\mathrm{bc}}$ & $1.32 \pm 0.01^{\mathrm{a}}$ \\
\hline Parthenium hysterophorus & $26.81 \pm 0.08^{c}$ & $39.42 \pm 0.03^{\mathrm{ab}}$ & $17.11 \pm 0.03^{\mathrm{d}}$ & $0.87 \pm 0.05^{\mathrm{a}}$ \\
\hline Cynodon dactylon & $23.46 \pm 0.04^{\mathrm{cd}}$ & $41.76 \pm 0.02^{\mathrm{ab}}$ & $34.63 \pm 0.02^{\mathrm{ab}}$ & $1.41 \pm 0.01^{\mathrm{a}}$ \\
\hline Brachiaria ramose & $28.51 \pm 0.08^{\mathrm{bc}}$ & $21.53 \pm 0.07^{\mathrm{d}}$ & $31.71 \pm 0.12^{\mathrm{ab}}$ & $1.48 \pm 0.02^{\mathrm{a}}$ \\
\hline Cyperus rotundus & $35.82 \pm 0.07^{\mathrm{a}}$ & $32.18 \pm 0.07^{\mathrm{c}}$ & $34.59 \pm 0.13^{\mathrm{ab}}$ & $0.87 \pm 0.06^{\mathrm{a}}$ \\
\hline Overall Mean & $30.29 \pm 3.93^{\mathrm{bc}}$ & $35.42 \pm 4.18^{\mathrm{ab}}$ & $29.90 \pm 3.69^{\mathrm{bc}}$ & $1.16 \pm 0.08^{\mathrm{a}}$ \\
\hline
\end{tabular}

Mean values having same letters in a column indicate insignificant $(P>0.05)$ results

Pasroor tehsils, while minimum $(24.49 \pm 2.34 \mathrm{mg} / \mathrm{kg})$ from tehsil Sialkot. The maximum concentration of Co $(1.22 \pm$ $0.26 \mathrm{mg} / \mathrm{kg}$ ) was found in forages collected from Daska tehsil, while minimum $(1.07 \pm 0.24 \mathrm{mg} / \mathrm{kg})$ in tehsil Sialkot (Fig. 1).

\section{Trace elements profile of soil}

Mean concentration of $\mathrm{Zn}$ in grazing field soil showed an insignificant result in all tehsils of study district. Soils from grazing sites of tehsil Sialkot contained maximum $(6.36 \pm$ $1.32 \mathrm{mg} / \mathrm{kg}$ ) concentration of $\mathrm{Zn}$ and minimum ( $4.84 \pm 0.46$ $\mathrm{mg} / \mathrm{kg}$ ) in the soil of tehsil Daska. The mean concentration of $\mathrm{Cu}$ in soils also showed an insignificant variation in different tehsils. The highest $(2.16 \pm 0.45 \mathrm{mg} / \mathrm{kg})$ and lowest $(1.60 \pm 0.25 \mathrm{mg} / \mathrm{kg})$ concentration of $\mathrm{Cu}$ was found in soil collected from tehsils Pasroor and Daska, respectively. The mean concentration of $\mathrm{Mn}$ of grazing sites soil varied insignificantly (Fig. 1).

\section{Trace element profile of sheep sera}

The mean concentration of $\mathrm{Zn}$ showed significant results among tehsils while, $\mathrm{Cu}, \mathrm{Mn}$, and $\mathrm{Co}$ in serum showed insignificant $(P>0.05)$ results among all tehsils. Serum samples of sheep population belonging to Pasroor tehsils showed a maximum concentration of $\mathrm{Zn}(1.13 \pm 0.90)$ while serum of sheep population from Sialkot tehsil showed minimum $(0.59 \pm 0.15) \mathrm{Zn}$ concentration. Maximum $(1.31 \pm 0.12)$ mean concentration of $\mathrm{Cu}$ was found in serum samples collected from tehsil Pasroor while minimum $(1.05 \pm 0.14)$ from Sialkot tehsil. Serum samples of sheep collected from tehsil Daska showed maximum $(0.18 \pm 0.06)$ concentration of $\mathrm{Mn}$ in serum while serum collected from tehsil Pasroor showed minimum $(0.15 \pm 0.06)$ concentration. The mean concentration of Serum Co was highest $(0.59 \pm 0.38)$ in tehsil Daska and lowest $(0.41 \pm 0.33)$ in Sialkot tehsil (Fig. 1). 
Table 4: Correlation of the selected trace elements of serum with mean parasitic eggs per gram of faeces various tehsils of district Sialkot, Punjab, Pakistan

\begin{tabular}{lllll}
\hline Tehsils & Correlations & Zn & Cu & Mn \\
\hline Daska & Pearson Correlation & 0.005 & -0.039 & 0.080 \\
& Sig. (2-tailed) & 0.949 & 0.634 & 0.336 \\
Sialkot & Pearson Correlation & 0.124 & -0.055 & -0.051 \\
& Sig. (2-tailed) & 0.211 & 0.579 & 0.558 \\
Pasror & Pearson Correlation & -0.002 & -0.237 & 0.146 \\
& Sig. (2-tailed) & 0.985 & 0.006 & -0.200 \\
\hline
\end{tabular}
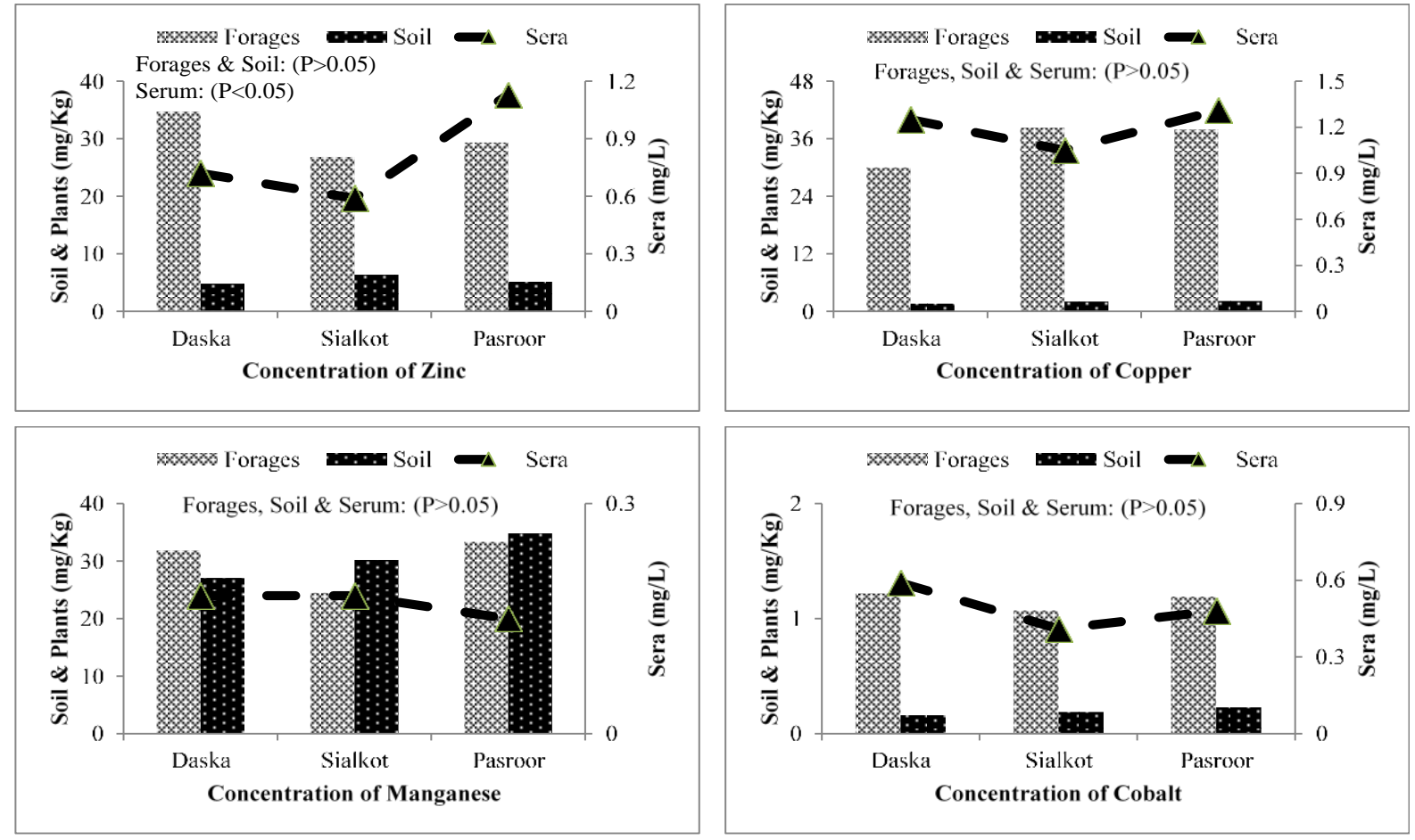

Fig. 1: Association of trace elements of soil-plant-serum in each tehsil of Sialkot district

\section{Soil-plant-serum trace element correlation analyses}

The relationship of trace elements of soil-plant-serum in each tehsil of Sialkot district is given in Fig. 1. The concentration of $\mathrm{Zn}$ in serum showed significant variation among all tehsils while in forages and soil showed insignificant results. However, the concentration of $\mathrm{Cu}, \mathrm{Mn}$, and Co showed insignificant results in soil-plant-animal in all tehsils. The mean concentration of Co in serum was directly related to the mean concentration of Co in forages in different tehsils of study district, while the concentration of $\mathrm{Zn}, \mathrm{Cu}$, and $\mathrm{Mn}$ showed variable (directly or indirectly proportional) results in all tehsils of study area.

\section{Correlation of serum trace elements with egg per gram of sheep faeces}

A correlation of the trace element of serum with mean EPG of each tehsil of district Sialkot is given in Table 4. Mean concentrations of serum $\mathrm{Cu}$ and $\mathrm{Mn}$ directly correlate to the mean EPG of sheep in tehsils Pasroor of Sialkot district. It showed that the high level of these trace elements decreases the burden of GI parasites, whereas, the mean concentration of $\mathrm{Co}$ and $\mathrm{Zn}$ showed insignificant results concerning the mean EPG in all tehsils of district Sialkot.

\section{Discussion}

Parasites identified in the sheep population in the present study were also reported by various scientists from different localities of Pakistan (Ayaz et al. 2013; Ahmad et al. 2017; Qudoos et al. 2017; Ahmad et al. 2020). The same species of parasites were also reported in different parts of the world like Bangladesh (Mohanta et al. 2007), Kenya (Kanyari et al. 2009) and Ethiopia (Dagnachew et al. 2011). Other species of parasites have also been reported by various scientists (Khaled et al. 2016; Yimer and Birhan 2016; Getachew et al. 2017). Distribution of different parasitic species in different areas may be attributed to certain factors including age, breed, nutrition, health, availability of infective larvae, climate and management systems (Blackie 2014; Abdela and Jilo 2016). Moreover, the incidence of a 
particular parasitic species in a particular area is directly associated with the affected species of animal and environmental conditions.

The reason for the higher incidence of GI parasites is probably due to their grazing behaviour which enhances the acquirement of the infective parasitic stage. The higher prevalence of GI parasites may also be due to meager animal care infrastructure and the management of animals under extensive pastoralism. Relatively low prevalence of sheep GI parasites may be due to certain factors like epidemiological patterns, parasitic species, breed variation, age and sex of host, management practices and environmental conditions (Nwosu et al. 2007). Sheep grazed in rangelands of all tehsils of the study area exhibited almost similar prevalence of GI parasites. This similarity may be linked to the acquisition of worms by host species in these areas and may be joined with similar rainfall and humidity at these sites. The prevalence of parasites reported in sheep populations varies around the world. The prevalence of parasites can be influenced by a variety of factors such as standard of management, education level and economic capacity of the farmers, grazing habits, irrational use of anthelmintic, seasonal difference, variation in agroecology of the study area besides poorly drained land, lack of fences around the farms, combined grazing of male, female, young and adult animals, predominant agro-climatic conditions, and overstocking of animals (Lashari and Tasawar 2011; Nana 2016).

The rangelands of any country play an important role in the economy because they are used for the grazing of livestock. The topographical regions, ecological zones and climatic conditions of Pakistan are very favorable for a variety of natural vegetations suitable for the consumption by animals. Almost $60 \%$ of the livestock population of Pakistan is reared by grazing (Mirza 2007). Various forage species have been identified around the world consumed by livestock (Mashwani et al. 2012). The variation in plantation diversity may be linked with the topography of a particular region, structure of soil and specific conditions of climate (Nordløkken et al. 2015).

For determination of trace elements, analysis of forages should be a routine practice because level of trace elements of forages consumed by animals reflect the level of trace elements in grazing animals (McDowell and Arthigton 2005; Hoste et al. 2006). Gomide (1978) documented that composition of trace elements of forages depends on seasion, age and species of plants, soil type, and use of fertilizers in grazing areas. These factors largely cause variations in the minerals composition of forages (Ahmad et al. 2012). A deficiency of Zn has been reported in the livestock population subjected to graze in $\mathrm{Zn}$ deficient rangelands or areas having a high level of $\mathrm{Fe}, \mathrm{Cd}$, $\mathrm{Mn}, \mathrm{S}$ and Mo which interact with $\mathrm{Zn}$ and reduce its utilization in animals (Ndebele et al. 2005). The low level of soil $\mathrm{pH}$ affects the concentration of $\mathrm{Cu}$ in plants because low $\mathrm{pH}$ increases the solubility of Fe which decreases the absorption of $\mathrm{Cu}$ (Beeson and Matrone 1976). The presence of $\mathrm{Mo}, \mathrm{Ca}$, and $\mathrm{S}$ act as an antagonist for $\mathrm{Cu}$ which shows that a higher level of these elements in soil decrease the level of $\mathrm{Cu}$ in forages (McDowell 2003). The forage $\mathrm{Mn}$ level depends on the level of $\mathrm{Mn}$ in soil, but it has also been reported that the livestock gets an adequate amount of Mn even in Mn deficient soil (Underwood 1981). The deficiency of Co in grazing animals causes severe effects (McDowell et al. 1984). The concentration of $\mathrm{Co}$ in forages depends upon the concentration of $\mathrm{Mn}$, the higher the level of Mn in soil, the lower the absorption of Co in forages (McKenzie 1975).

Soil is the direct and indirect source of trace elements for livestock. The bioavailability of these trace elements to the livestock is associated with their level in the soil (Reid and Horvath 1980), lime, pH, soil quality, electrical conductivity, plant species and seasons (Khan et al. 2004). The presence of antagonistic trace elements can decrease or increase the uptake of other trace elements (Mitchell and Gray 2003). Reproductive problems and poor growth have been reported for animals in the areas having soil with a low level of trace elements (Tiffany et al. 2000). The production level of the livestock population of tropics and sub-tropical areas is severely affected by the low level of trace elements in soils (McDowell 1985). Analysis of soil to determine the level of trace elements is important to endorse the mineral supplements for grazing livestock.

For the determination of trace element level in animals, the analysis of blood is a well-established and recognized tool (Mills 1987). The overall concentration of trace elements required by animals is less than $100 \mathrm{mg} / \mathrm{kg}$ dry matter (McDowell 1992). However, the level of trace elements retained in the serum of animals is below $2 \mathrm{mg} / \mathrm{L}$ (Suttle 2010). The requirement and level of trace elements in serum vary depending upon various factors like age, sex, breed, genotype and production capabilities (NRC 2001; Marques et al. 2003; Lukić et al. 2009; Suttle 2010; Yatoo et al. 2012). Various factors (age, sex, disease, stress conditions and feed) have been reported to alter the level of trace elements in general and $\mathrm{Zn}$ specifically in animals (Devi et al. 2011; Ishag et al. 2014). Variation in the level of trace elements may also be due to prompt growth of animals and the presence of inhibitors in the food of animals (Mills 1981). A lower level of serum $\mathrm{Zn}$ and $\mathrm{Cu}$ have been reported in animals having a parasitic infection or certain other diseases as compared to healthy animals (Fouda et al. 2013).

In animals, trace elements act as a cofactor and are required for the proper functioning of the immune system. Adequate level of trace elements helps reduce various pathogens attack (Erdoğan et al. 2002; McClure 2008). A significant association of increased level of trace elements in serum like Cd (Aypak et al. 2016), $\mathrm{Cu}$ and $\mathrm{Zn}$ (Rizwan et al. 2019) and Mn (Ahmad et al. 2020), decreasing the level of parasitic burden is reported with GI parasitic burden. 
Trace elements in serum like $\mathrm{Mo}, \mathrm{Zn}, \mathrm{Se}, \mathrm{Co}, \mathrm{Mn}, \mathrm{Cu}$ (Qudoos et al. 2017) and $\mathrm{P}, \mathrm{Cu}, \mathrm{Ca}$, and $\mathrm{Zn}$ showed an insignificant association with GI parasitic burden (Aypak et al. 2016). Schafer et al. (2015) reported a lower burden of GI parasites in animals having a higher level of Co and vice versa. Sheep population infected with Trichostrongylus (T.) colubriformis and T. axei showed a lower level of $\mathrm{Cu}$ in the serum (Hucker and Yong 1986). Animals with a lower level of $\mathrm{Cu}$ and $\mathrm{Zn}$ in serum showed a higher burden of $H$. contortus and Trichostrongylus (Silva et al. 1978; Abdellall 1991).

\section{Conclusion}

Sheep population of Sialkot district is infected with a variety of parasitic infections. Most of the study animals showed a high burden of parasitic infection. The species of forages present in the study area are rich with trace elements. Trace elements like $\mathrm{Cu}$ and $\mathrm{Zn}$ were found suitable for the control of parasitic infection. However, further control studies are required to determine the role of trace elements in animals and the association of trace elements with specific GI parasites. It is also recommended to determine the presence and association of various antiparasitic compounds of forages like tannin with trace elements and GI parasites.

\section{Acknowledgments}

Authors are very thankful to Prof. Abdul Wahid, Department of Botany, University of Agriculture, Faisalabad, Pakistan for the identification of plants species. This study is a part of Higher Education Commission (HEC), Islamabad, Pakistan funded project No. 202666/NRPU/R\&D/HEC/12/6974.

\section{Author Contributions}

MSS, ZI and RN conceived and planned the experiments. HMR, HA, MA, AQ, AS and MS contributed to sample preparation and carried out the experiments. HMR, MSS and MS contributed to the interpretation of the results. HMR and MSS took the lead in writing the manuscript. AW identified the forages species. ZI supervised the project. MSS and GH contributed to the final version of the manuscript.

\section{Conflicts of Interest}

The authors declare that they have no conflict of interest.

\section{Data Availability}

We hereby declare that all data reported in this paper are available and will be produced on demand.

\section{Ethics Approval}

Standard guidelines for the institutional animal care and use (IACU), University of Agriculture, Faisalabad, Pakistan were followed in this study.

\section{References}

Abdela N, K Jilo (2016). Impact of climate change on livestock health: A Review. Glob Vet 16:419-424

Abdellall TS (1991). Haematological and biochemical studies on the efficacy of synanthic against gastrointestinal parasites in sheep. Assiut Vet Med J 24:197-203

Ahmad K, ZI Khan, M Ashraf, A Ejaz (2012). Appraisal of temporal variation in soil and forage iron and zinc in a pasture under semi-arid environmental conditions. Pak J Bot 44:157-160

Ahmad M, MN Khan, MS Sajid, G Muhammad, A Qudoos, HM Rizwan (2017). Prevalence, economic analysis and chemotherapeutic control of small ruminant fasciolosis in the Sargodha district of Punjab, Pakistan. Vit Ital 53:47-53

Ahmad S, MS Sajid, MK Khan, R Nadeem, HM Rizwan, MA Malik, F Yosuf (2020). Effect of trace element supplementation on the gastrointestinal parasites of grazing sheep of Multan district, Pakistan. J Anim Plant Sci 30:72-80

Amacher MC (1996). Nickel, Cadmium and Lead. In: Methods of Soil Analysis. Part 3: Chemical Methods, $3^{\text {rd }}$ edn., pp:739-768. Sparks DL (Ed.). SSSA/ASA, Madison, Wisconsin, USA

Anonymus (2016). Punjab Development Statistics. Bureau of Statistics Planning and Development Department, Government of Punjab, Pakistan

Ayaz MM, MA Raza, S Murtaza, S Akhtar (2013). Epidemiological survey of helminths of goats in southern Punjab, Pakistan. Trop Biomed 301:62-71

Aypak SU, S Aypak, H Voyvoda, G Güven, ED Fidan, G Tosun, M Gültekin, E Şimşek, AG Güler (2016). Comparative analysis of serum mineral levels and parasite load in goats naturally infected with gastrointestinal nematodes. Turk Parazitol Derg 40:141-146

Badar N, Z Iqbal, MS Sajid, HM Rizwan, A Jabbar, W Babar, MN Khan, A Ahmed (2017). Documentation of ethnoveterinary practices in district Jhang, Pakistan. J Anim Plant Sci 27:398-406

Beeson KC, G Matrone (1976). The Soil factor in nutrition: Animal and Human. Marcel Decker, Inc., New York, USA

Biu AA, A Maimunatu, AF Salamatu, ET Agbadu (2009). A faecal survey of gastrointestinal parasites of ruminants on the University of Maiduguri Research Farm. Intl J Biomed Health Sci 5:175-179

Blackie S (2014). A review of the epidemiology of gastrointestinal nematode infections in sheep and goats in Ghana. J Agric Sci 6:109-118

Caroprese M, F Napolitano, S Mattiello, GC Fthenakis, O Ribó, A Sevi (2016). On-farm welfare monitoring of small ruminants. Small Rumin Res 135:20-25

Dagnachew S, A Amamute, W Temegen (2011). Epidemiology of gastrointestinal helminthiasis of small ruminants in selected sites of north Gondar zone, northwest Ethiopia. Ethiop Vet J 15:57-68

Devi S, MI Yatoo, P Kumar, R Tiwari, MC Sharma (2011). Evaluation of micro mineral profile in the growing Vrindhavani cattle. Ind $J$ Vet Med 31:109-111

Erdoğan S, Y Ergün, Z Erdoğan, T Kontas (2002). Hatay bölgesinde yetiştirilen koyun ve keçi serumlarında bazı mineral madde düzeyleri. Türk J Vet Anim Sci 26:177-182

Fekete SG, RO Kellems (2007). Interrelationship of feeding with immunity and parasitic infection: A review. Vet Med 52:131-143

Fouda TA, MA Youssef, MR Al-Ashkar (2013). Chronic fascioliasis as cause of unthriftiness in sheep with reference to its impacts on blood constituents. J Anim Res 3:209-221

Getachew M, R Tesfaye, E Sisay (2017). Prevalence and risk factors of gastrointestinal nematodes infections in small ruminants in Tullo district, western Harerghe, Ethiopia. J Vet Sci Technol 8; Article 428 
Gomide AJ (1978). Mineral composition of grasses and tropical leguminous forages. In: Latin American Symposium on Mineral Nutrition with Grazing Ruminants, pp:32-40. Conrad JH, LR McDowel (Eds.). University of Florida, Gainesville, Florida, USA

Haswell SJ (1991). Atomic Absorption Spectrometry, Theory, Design and Applications. Elsevier, Amsterdam, Netherlands

Hoste H, F Jackson, S Athanasiadou, SM Thamsborg, SO Hoskin (2006). The effects of tannin-rich plants on parasitic nematodes in ruminants. Trends Parasitol 22:253-261

Hucker DA, WK Yong (1986). Effects of concurrent copper deficiency and gastrointestinal nematodes on circulating copper and protein levels, liver copper and body weight in sheep. Vet Parasitol 19:67-76

Ishag HI, IG Ibrahim, AM Shamat, A Aisha, SH Eisa (2014). Mineral profile of sheep and goats grazed natural pasture in Nyala locality, western Sudan. J Agric Vet Sci 15:53-61

Kanyari PWN, JM Kagira, RJ Mhoma (2009). Prevalence and intensity of endoparasites in small ruminants kept by farmers in Kisumu Municipality, Kenya. Livest Res Rur Dev 21:1-10

Kebede A, S Ayalew, A Mesfin, G Mulualem (2017). An ethnoveterinary study of medicinal plants used for the management of livestock ailments in selected Kebeles of Dire Dawa Administration, eastern Ethiopia. J Plant Sci 5:34-42

Khaled S, W Elmonir, Y Hegazy (2016). Gastrointestinal parasites of sheep in Kafrelsheikh governorate, Egypt: Prevalence, control and public health implications. Beni-suef Univ J Basic Appl Sci 5:79-84

Khan ZI, S Omar, K Ahmad, H Bashir, M Sohail, M Ayub, N Mahmood (2017). Assessment of macro minerals and their distribution and concentration in soil-plant-animal systems in Shor Kot, Pakistan. $J$ Dairy Vet Anim Res 5:38-42

Khan ZI, A Hussain, M Ashraf, MY Ashraf, LR McDowell (2007). Macromineral status of grazing sheep in a semi-arid region of Pakistan. Small Rumin Res 68:279-284

Khan ZI, A Hussain, M Ashraf, MY Ashraf, EE Valeem, MS Ahmad (2004). Soil and forage (Trace elements) status of a grazing pasture in the semiarid region of Pakistan. Pak J Bot 36:851-856

Lashari MH, Z Tasawar (2011). Prevalence of some gastrointestinal parasites in sheep in southern Punjab, Pakistan. Pak Vet $J$ 31:295-298

Lateef M, Z Iqbal, MN Khan, MS Akhter, A Jabber (2003). Anthelmintic activity of Adhatoda vasica roots. Intl J Agric Biol 5:86-90

Lukić M, Z Pavlovski, Z Škrbić (2009). Mineral nutrition of modern poultry genotypes. Biotechnol Anim Husb 25:399-409

Marques AP, F Riet-Correa, MP Soares, EL Ortolani, MJ Giuliodori (2003). Sudden deaths in cattle associated with copper deficiency. Pesq Vet Bras 23:21-32

Mashwani ZUR, MA Khan, M Ahmad, M Zafar, NI Raja, M Arshad, Samiullah (2012). Macro-mineral quantification of the forage grass species in the Gandgar hills, western Himalaya, Pakistan. Pak J Bot 44:117-121

McClure SJ (2008). How minerals may influence the development and expression of immunity to endoparasites in livestock. Parasite Immunol 30:89-100

McDowell LR (2003). Minerals in Animals and Human Nutrition, $2^{\text {nd }}$ edn. Elsevier Science BV Amsterdam, Netherlands

McDowell LR (1992). Minerals in Animal and Human Nutrition. Academic Press Inc. Harcourt Brace Jovanovich Publishers, San Diego, California, USA

McDowell LR (1985). Nutrition of Grazing Ruminants in Warm Climates. Academic Press, Orlando, Florida, USA

McDowell LR, JD Arthington (2005). Minerals for Grazing Ruminants in Tropical Regions, $5^{\mathrm{th}}$ edn. University of Florida, Gainesville, Florida, USA

McDowell LR, JH Conrad, GL Ellis (1984). Mineral deficiencies and imbalances and their diagnosis. In: Symposium on Herbivores Nutrition in Sub-Tropics and Tropics: Problems and Prospects, pp:67-88. Gilchrist FMC, RI Mackie (Eds.). Craighall, South Africa

McKenzie RM (1975). The mineralogy and chemistry of soil cobalt. In: Trace Elements in Soil-Plant-Animal System, pp:83-93. Nicholas DJD, AE Eagan (Eds.). Academic Press, Inc., New York, USA
Miller RO (1998). Nitric-perchloric acid wet digestion in an open vessel. In: Handbook of Reference Methods for Plant Analysis, pp:57-61. Kalra YP (Ed.). CRC Press, Boca Raton, USA

Mills CF (1987). Biochemical and physiological indicators of mineral status in animals: Copper, cobalt and zinc. J Anim Sci 65:1702-1711

Mills CF (1981). Some outstanding problems in the detection of trace element deficiency diseases. Phil Trans Roy Soc Lond B Biol Sci 294:199-213

Mirza SN (2007). Range land resources of Pakistan. Issues and potentials. In: International Conference on Biological Resources of Pakistan: Problems, Success and Future Perspectives. 25-27 April, 2007. University of Arid Agriculture, Rawalpindi, Pakistan

Mitchell L, D Gray (2003). Are your livestock getting enough? Org Farm 80:24-25

Mohanta UK, T Anisuzzaman, PM Das, S Majumder, MMH Mondal (2007). Prevalence population dynamics and pathological effects of intestinal helminths in Black Bengal goats. Bang J Vet Med 5:63-69

Nana T (2016). Prevalence of ovine gastrointestinal nematodes in Meskan district, Gurage zone, southern Ethioipa. Intl J Adv Multidiscipl Res 3:22-30

Ndebele N, JP Mtimuni, IDT Mpofu, S Makuza, P Mumba (2005). The status of selected minerals in soils, forage and beef cattle tissues in a semi-arid region of Zimbabwe. Trop Anim Helth Prod 37:381-393

Nordløkken M, T Berg, TP Flaten, E Steinnes (2015). Essential and nonessential elements in natural vegetation in southern Norway: Contribution from different sources. Sci Tot Environ 502:391-399

NRC (2001). Nutrient Requirements of Domestic Animals. Nutrient Requirements of Dairy Cattle, $7^{\text {th }}$ edn. National Academy of Sciences, Washington, DC, USA

Nwosu CO, PP Madu, WS Richards (2007). Prevalence and seasonal changes in the population of gastrointestinal nematodes of small ruminants in the semi-arid zone of north-eastern Nigeria. Vet Parasitol 144:118-124

Peixoto MG, LM Costa-Júnior, AF Blank, AS Lima, TSA Menezes, DA Santos, PB Alves, SCH Cavalcanti, L Bacci, MF Arrigoni-Blank (2015). Acaricidal activity of essential oils from Lippia alba genotypes and its major components carvone, limonene, and citral against Rhipicephalus microplus. Vet Parasitol 210:118-122

Qadir S, KA Dixit, P Dixit (2010). Use of medicinal plants to control Haemonchus contortus infection in small ruminants. Vet World 3:515-518

Qudoos A, MN Khan, MS Sajid, G Muhammad (2017). Correlation of trace mineral profiles with gastrointestinal worm burden in rangeland sheep of Chakwal District, Punjab, Pakistan. Intl J Agric Biol 19:140-144

Raza MA, M Younas, E Schlecht (2014). Prevalence of gastrointestinal helminths in pastoral sheep and goat flocks in the Cholistan desert of Pakistan. J Anim Plant Sci 24:127-134

Reid RL, DJ Horvath (1980). Soil chemistry and mineral problems in farm livestock: A review. Anim Feed Sci Technol 5:95-167

Richards LA (1968). Digestion and Improvement of Saline and Alkaline Soil, $1^{\text {st }}$ edn. IBH Publishing Co., New Delhi, India

Rizwan HM, MS Sajid, Z Iqbal, M Saqib (2019). Association of phytomineral with gastrointestinal parasites of grazing sheep in Sialkot district, Punjab, Pakistan. Pak J Agric Sci 56:459-468

Rizwan HM, MS Sajid, Z Iqbal, M Saqib (2017). Point prevalence of gastrointestinal parasites of domestic sheep (Ovis aries) in district Sialkot, Punjab, Pakistan. J Anim Plant Sci 27:803-808

Schafer AS, MLR Leal, MB Molento, AR Aires, MMMF Duarte, FB Carvalho, AA Tonin, L Schmidt, EMM Flores, RT Franca, TH Grando, AP Minho, A Krause, AQ Antoniazzi, STA Lopes (2015). Immune response of lambs experimentally infected with Haemonchus contortus and parenterally treated with a combination of zinc and copper. Small Rumin Res 123:183-188

Schork MA, RD Remington (2010). Statistics with Applications to the Biological and Health Sciences, $3^{\text {rd }}$ edn. Lexington, Kentucky, USA

Silva RM, JM Ferrerra-Neto, IBM Sampaio (1978). The influence of diet and gastrointestinal parasites on serum copper and zinc in sheep (Abst). Arq Esc Vet Univ Minas Gerais 30:261-274

Smith MC, DM Sherman (2009). Goat Medicine, $2^{\text {nd }}$ edn. Wiley-Blackwell. New Jersey, USA 
Rizwan et al. / Intl J Agric Biol, Vol 26, No 1, 2021

Soulsby EJL (1982). Helminths, Arthopods and Protozoa of Domesticated Animals, $7^{\text {th }}$ edn. ELBS, Baillere Tindall, London, UK

Suttle NF (2010). Mineral Nutrition of Livestock, $4^{\text {th }}$ edn. CABI Publishing, Wallingford, UK

Terefe D, D Demissie, D Beyene, S Haile (2012). A prevalence study of internal parasites infecting Boer goats at Adami Tulu Agricultural Research Center, Ethiopia. J Vet Med Anim Health 4:12-16

Tiffany ME, LR McDowell, GA O'Connor, H Nguyen, FG Martin, NS Wilkinson, EC Cardoso (2000). Effects of pasture applied biosolids on forage and soil concentrations over a grazing season in north Florida. I. Macrominerals. Crude protein and in vitro digestibility. Commun Soil Sci Plant Anal 31:201-203
Tugume P, E Kakudidi, M Buyinza, J Namaalwa, M Kamatenesi, P Mucunguzi, J Kalema (2016). Ethnobotanical survey of medicinal plant species used by communities around Mabira Central Forest Reserve, Uganda. J Ethnobiol Ethnomed 12; Article 5

Underwood EJ (1981). The Mineral Nutrition of Livestock, Commonwealth Agricultural Bureau, England

Yatoo MI, S Devi, P Kumar, R Tiwari, MC Sharma (2012). Evaluation of micro mineral profile in the growing male and female Vrindhavani cattle. Ind J Vet Med 32:96-98

Yimer A, E Birhan (2016). Prevalence and identification of gastrointestinal nematodes of small ruminants in northern Ethiopia. Middle-East $J$ Sci Res 24:2602-2608 